TABLE 1

Trace-Element Composition of Two Valencia Trough Volcanic Rocks

\begin{tabular}{lcc}
\hline & Sample $13-122-4 \mathrm{~A}-2$ & Sample $13-123-8-\mathrm{CC}$ \\
\hline $\mathrm{Rb}$ & $45 \mathrm{ppm}$ & $215 \mathrm{ppm}$ \\
$\mathrm{Sr}$ & $850 \mathrm{ppm}$ & $42 \mathrm{ppm}$ \\
$\mathrm{Y}$ & $65 \mathrm{ppm}$ & $50 \mathrm{ppm}$ \\
$\mathrm{Zr}$ & $300 \mathrm{ppm}$ & $215 \mathrm{ppm}$ \\
$\mathrm{Nb}$ & $60 \mathrm{ppm}$ & $25 \mathrm{ppm}$ \\
\hline
\end{tabular}

Analyst: J. R. Cann.

\title{
28.4. RADIOMETRIC DATING OF THE VALENCIA VOLCANIC ROCKS
}

\author{
G. Ferrara, G. Bigazzi, F.P. Bonadonna and O. Giuliani, Laboratorio per Ricerche RAdiometriche Applicate all \\ Geocronologia e alla Paleoecologia, CNR, Pisa, Italy
}

A dacite ash from Site 123 in the Valencia Trough was sent to Professor Ferrara, Laboratorio per Ricerche Radiometriche Applicate, Pisa, for radiometric dating. Both whole-rock $\mathrm{K} / \mathrm{Ar}$ and fission-track methods have been used. The results are as indicated below.

\section{FISSION TRACKS RESULTS}

The sample studied consists of very small fragments of glass, either transparent or opaque. The sample was mounted in epoxy and a polished section was made. This allowed us to count the track density on the interior surface alone. In this way it was also possible to minimize uranium contamination.

Two separate portions of the sample were used for the counting of induced and natural fission tracks because the size of the glass fragments does not allow two subsequent

TABLE 1

\begin{tabular}{lcccc}
\hline Sample & $\begin{array}{c}\text { Natural } \\
\text { Tracks } \\
\text { Density F }\end{array}$ & $\begin{array}{c}\text { Induced } \\
\text { Tracks } \\
\text { Density I }\end{array}$ & $\begin{array}{c}\text { Thermal } \\
\text { Neutron } \\
\text { Dose }\end{array}$ & Age m.y. \\
\hline $\begin{array}{l}\text { Leg 13 } \\
\text { Station 123 } \\
\text { Barrel 6 } \\
\text { Section CC }\end{array}$ & $28 \times 10^{3}$ & $140 \times 10^{3}$ & $1.8 \times 10^{15}$ & $22.4 \pm 2.2$ \\
Sample CT & & & & \\
\hline
\end{tabular}

polishings on the same section. The track density uniformity favored use of this technique. The samples were etched with hydrofluoric acid ( $40 \%$ by volume) for 1 minute at $20^{\circ} \mathrm{C}$.

\section{K-Ar MEASUREMENTS}

Ar was extracted and measured using the standard methods routinely employed in this laboratory. A continuous spike system is used. The mass spectrometric measurement was performed by means of a Reynolds type glass mass spectrometer running at static conditions. $\mathrm{K}$ was determined by flame photometry using a Perkin-Elmer photometer with $\mathrm{Li}$ as internal standard.

Two different fractions of the sample were measured, and the results are shown in Table 2.
TABLE 2

\begin{tabular}{lcccc}
\hline $\begin{array}{c}\text { Sample } \\
\text { Fraction }\end{array}$ & $\mathrm{K} \%$ & $\frac{\mathrm{rd} \mathrm{Ar} 40 \mathrm{ccSTP}}{-\mathrm{gr} \mathrm{K}}$ & \% rd Ar 40 & Age m.y. \\
\hline $0.27 \mathrm{~mm}$ & 3.12 & $8.58 \times 10^{-5}$ & 32 & $21.4 \pm 0.6$ \\
0.16 & 2.77 & $8.13 \times 10^{-5}$ & 11 & $19.3 \pm 0.7$ \\
\hline
\end{tabular}

Measurements performed at the Laboratorio per Ricerche RAdiometriche applicate all Geocronologia e alla Paleoecologia, CNR, Pisa (directed by Prof. Giorgio Ferrara) by G. Bigazzi and F. P. Bonadonna (fission tracks) and $\mathrm{O}$. Giuliana (K/Ar). 